\title{
TRIBOLOGY OF PEKMEZ (GRAPE MOLASSES)-TAHİN (SESAME PASTE) MIXTURES
}

\author{
İpek Altay, Filiz Lokumcu Altay* \\ Istanbul Technical University, Ayazaga Campus, School of Chemical-Metallurgical, Department of Food \\ Engineering, Istanbul, Turkey
}

Received / Geliş: 15.02.2018; Accepted / Kabul: 04.06.2018; Published online / Online bask1: 27.06.2018

Altay, İ., Lokumcu Altay, F. (2018). Tribology of Pekmez (Grape Molasses)-Tahin (Sesame Paste) mixtures. GIDA (2018) 43 (4): 582-590 doi: 10.15237/gida.GD18026

\begin{abstract}
A new field of texture analysis called "tribology" or "thin film rheology" that might explain the food texture throughout oral processing has become important. In this study, tribological experiments for samples containing pekmez and tahin at 30:70, 40:60 and 50:50 (w/w) were conducted by using a modified pin-ondisk tribometer. In the Stribeck curves hydrodynamic and boundary regions were determined. For the mixture containing pekmez:tahin at 50:50, hydrodynamic region started at a lower speed compared to other samples, which indicated a developing a thin lubrication film between contact surfaces. The friction decreased with the oil content of the sample. This was more profound in the lower speed region for all samples. Tribological data provided more distinct evaluation compared to the viscosity data which were close to each other due to similar composition of samples. Further research are needed on tribological properties of foods, their relation to rheology and sensory analysis.
\end{abstract}

Keywords: tribology, friction, lubrication, sesame paste, grape molasses

\section{PEKMEZ-TAHİN KARIŞIMLARININ TRİBOLOJİSİ}

\section{ÖZ}

Son zamanlarda, gıdanın ağızda çiğnenirkenki yapısını açıklayabilecek "triboloji” ya da "ince film reolojisi" adı verilen bir yaklaşım önemli hale gelmiştir. Bu çalışmada, ağırlıkça 30:70, 40:60, 50:50 oranlarındaki pekmez-tahin karışımlarının tribolojik deneyleri modifiye edilmiş bir sensörle tribometre kullanılarak yürütülmüştür. Bu ölçümlerden sürükleme hızına karşı sürtünme katsayılarının çizildiği Stribeck eğrisi adı verilen grafikleri elde edilmiştir. Bu grafiklerde her bir örnek için hidrodinamik (sürtünme viskozite yüzünden hız ile doğrusal olarak artar) ve sınır bölgeleri (nispeten sabit sürtünme görülür) tespit edilmiştir. Ağıllıkça 50:50 pekmez-tahin içeren örnek diğer örneklere göre daha düşük bir hızda, temas yüzeyleri arasında ince bir yağlama tabakasının geliştiğini gösteren hidrodinamik bölgeye girmiştir. Diğer yandan sürtünme, örneklerin yağ içeriği arttıkça azalmıştır. Bu durum bütün örnekler için düşük hız bölgesinde daha belirgindir. Bileşimi birbirine yakın dolayısıyla viskoziteleri birbirine yakın bu örneklerin tribolojik ölçümleri, yapısal farklılıkları daha iyi ortaya koymuştur. Gıdaların tribolojik özellikleri, bunların reolojik ve duyusal özelliklerle ilişkisinin araştırılması için çalışmalar yapılması gerekmektedir.

Anahtar kelimeler: triboloji, sürtünme, yağlama, tahin, pekmez

${ }^{*}$ Corresponding author/Yazışmalardan sorumlu yazar

$\triangle$ lokumcu@itu.edu.tr

(f) (+90) 2122856948

冝 $(+90) 2122857333$ 


\section{INTRODUCTION}

Oral sensation (texture and mouthfeel) of a food product is one of the most significant quality factor that influences consumer acceptance and satisfaction about the product (Prakash et al., 2013). Oral processing of the food involves breaking and deforming the particles of foods besides continuous secration and interaction with saliva that leads to a mixing process. In the first responses against deformation of the food between the teeth and manipulation by the tongue can be explained by rheological and mechanical properties of the food. However, as the oral process continues, chewing and mastication causes constant change of food condition. Some of these changes can be counted as reduction of particle size, wetting by saliva, softening due to moisture absorbtion etc. Consequently, sensory feel of the food might be very distinctive (especially change in length-scale) between the first and later stages of oral processing. It makes the rheological and mechanical food properties less dominant in the perception of texture (Prakash, 2017).

The study of tribology becomes more important in the food texture sensation through the later stages of oral processing since it investigates relative motion of interacting surfaces (Chen \& Stokes, 2012). Lubrication, wear, and friction between surfaces with relative motion (food interacting with tongue, teeth, palate etc.) are analysed by tribological measurements which are more related to evaluation of oral processing of the food than rheological measurements that are based on shear deformation and bulk flow of the materials (Prakash, 2017). Another reason of limitation in texture studies with rheology approach and inconsistent findings on oral experience of shear rates might be subjective individuals and reasons in evaluation of texture sensation. Additionally, throughout the oral processing of foods, shearing length-scale keeps changing, due to continuous texture evolving, which may also cause incoherence. (Chen \& Stokes, 2012).

After realizing the limitation of rheological approaches to explain some parts of the oral sensation, tribology which is a study of thin film and lubrication, became more popular (Prakash et al., 2013). Tribology is discipline about friction, lubrication and wear of interacting surfaces with relative movement. Chen \& Stokes (2012) state that even a little observation of mouth proofs the significance of lubrication and tribology during oral processing. Additionally, tribology can be used for developing new formulates that lead to reduce some eating problems like worldwide fat related diseases.

Tribologly characterises food materials at constant load where the gap might differentiate till the point of two surfaces (tongue and palate) touch whereas a rheometer characterization of foods takes place in a fixed gap (Stokes, 2012). When the two surfaces in relative motion reach the steady speed $(V)$, the frictional force $\left(F_{R}\right)$ can be given as:

$\mathrm{F}_{\mathrm{R}}=\mu \times \mathrm{F}_{\mathrm{L}}$ $\mathrm{Eq}(1)$ where $\mu$ is dimensionless friction coefficient and $F_{L}$ is the normal force or surface load (N) (Prakash et al., 2013).

The Stribeck curve, which is a plot of friction coefficient against the combination of speed, load and viscosity, helps to explain lubrication behavior of food samples. In this plot, friction coefficient is indicated on the vertical axis while other parameter, that consists of the fluid viscosity, $\eta(\mathrm{Pa} . \mathrm{s})$, surface load $\mathrm{P}_{\mathrm{L}}(\mathrm{Pa})$ and relative speed of surfaces $V(\mathrm{~m} / \mathrm{s})$, is shown on the horizontal axis. It can be concluded that the combined parameter, which has a length unit (m), resembles the lubricant film thickness between the surfaces in relative motion. Generally, Stribeck curves show three different regimes which are boundary regime, mixed regime and hydrodynamic regime (Prakash et al., 2013). In the hydrodynamic regime, the aim of the lubrication is introducing a food film that has low-shearstrength between the palate and tongue. This lubricant film should be able to sustain the applied load by these two surfaces since it is wanted to be separate them. When the food entered to the mouth, the entrainment rate of the food has a sufficient high fluid pressure in order to completely separate the surfaces. That is called 
hydrodynamic lubrication. In this kind of lubrication, viscosity parameter of the food affects the generated friction and film thickness which means perceived sensory thickness depends on food viscosity. The mixed regime region stands in between boundary and hydrodynamic regimes. The food entrainment to the moving surfaces (palate-tongue) is not enough to separate them in the mixed regime unlike the complete separation in the hydrodynamic regime (Prakash et al., 2013). In that regime, friction coefficient decreases till a minimum and it might increase by elevated roughness contact or lubricant layer thickness (Dresselhuis et al., 2008). In addition, Malone et al. (2003) suggests that the friction measured in mixed regime is the most related regime to describe sliperiness and smoothness sensory perceptions during oral processes. In case of boundary regime, the lubrication features rely on capability of food constituents to form boundary films because of insufficient hydrodynamic fluid pressure to separate the tongue and palate surfaces. There is an "immobile" layer, which is an asperity contact point between two surfaces (tongue and palate), characteristic for that kind of regime. This layer does not involve in the hydrodynamic flow of the bulk food. That one is considered as the regime that is closely associated with sliperiness and astringency of human perceiption (Prakash et al., 2013).

The researchers adjust the roughness and wetting characteristics of the artificial surfaces instead of human tongue in tribology experiments. Mostly poly dimethyl siloxane (PDMS) is used (Dresselhuis et al., 2008). It has a low elasticity modulus and can easily be fabricated to desired shapes (e.g. spherical, plane) with smooth surface finishes (Lee \& Spencer, 2005).

Pekmez, has excellent nutritional properties, and is a popular traditional food in Turkey. Pekmez is a kind of fruit juice concentrate from mostly grape. The processing of pekmez includes washing, sorting, crushing, pressing and boiling of grape (Karababa \& Isikli, 2005). Tahin is obtained by milling roasted dehulled sesame seeds. It is rich in lipids, proteins, carbohydrates and dietary fiber (Arslan et al., 2005). Pekmez/tahin blends can be considered as an oil-in-water emulsion (Alparslan \& Hayta, 2002), however the type of the emulsion should depend on the ratios of pekmez and tahin. In this mixture, tahin is the oil phase and pekmez is the water phase. The stability of the blends can be attributed to sesame proteins acting as emulsifier at the oil-water interface (Arslan et al., 2005). Reliable rheological data is essential for design, process and quality control, sensory assesment, stability and consumer acceptane of a given product (Abu-Jdayil et al., 2002; Steffe, 1996). Even though there are research on rheology of pekmez, tahin and their blends (AbuJdayil et al., 2002; Alparslan \& Hayta, 2002; Arslan et al., 2005; Lokumcu \& Ak, 2000); there is no study on the tribological properties of these blends. Sensory perception and the preference of food products with high fat and sugar contents are affected by friction and lubrication between the tongue, palate, teeth, food products and saliva during oral processing (Campbell et al., 2017). Therefore, tribological analysis of pekmez-tahin blends may provide an evaluation for their lubrication behavior and the friction between moving surfaces which imitate oral surfaces.

The objective of this study was to determine the tribological properties of pekmez (grape molasses)- tahin (sesame paste) mixtures at the ratios of 30:70, 40:60 and 50:50. The outcomes of this study may be helpful to evaluate the structural behavior of these mixtures, which have very similar rheological parameters. In the future, tribology can be combined with rheology and sensory analysis for better understanding of the texture of any given food material from manufacturing to chewing/swallowing.

\section{MATERIALS AND METHODS \\ Materials \\ Preparation of PDMS}

Polydimethylsiloxane (PDMS) probes were prepared by using the Sylogard 184 elastomer kit (DOW Corning, USA) containing liquid PDMS and its curing agent (crosslinker : Dimethyl, methylhydrogen siloxane). The PDMS was mixed with the cross linker at a ratio of 10:1 with a magnetic stirrer and poured into the moulds. The moulds were chosen as $6 \mathrm{~mm}$ diameter for probes 
and as small cylindirical-shaped moulds for the disks. After filling the moulds, they were put into a vacuum oven in order to get rid of gas bubbles inside the PDMS mix. The oven was set to $60^{\circ} \mathrm{C}$ and waited for overnight to take out the moulds as shown in Figure 1.

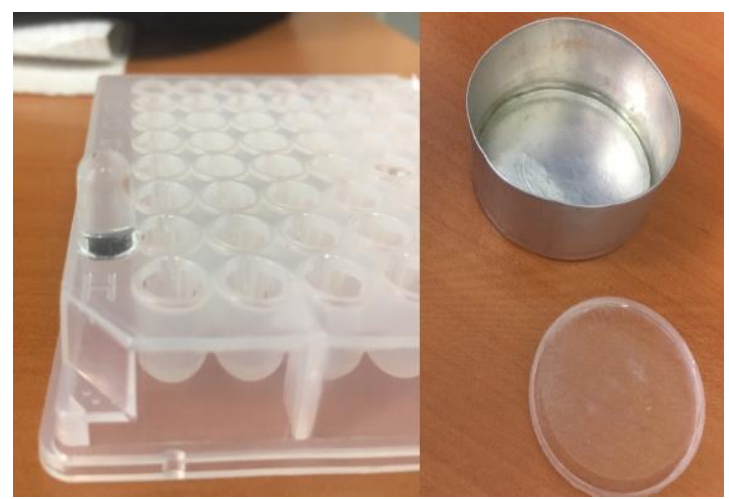

Figure 1. Prepared PDMS pin and disc for the tribological measurements

\section{Preparation of samples}

The commercial pekmez (grape molasses) and tahin (sesame paste) products were obtained from a local market. The ratios of pekmez (grape molasses):tahin (sesame paste) mixtures (w/w) were 30:70 (sample 1), 40:60 (sample 2) and 50:50 (sample 3). The reason for choosing these ratios was that tahin-dominated flavor in the mixture is preferred according to the talks with our colleaques, associates, friends and families. In addition, Arslan et al. (2005) reported that average acceptable ratio of pekmez to tahin in the blends as $40-60 \%$. Prior to the experiment in the tribometer, the mixtures are mixed with a spatula in order to obtain a homogenous mixture.

\section{Methods \\ Tribological measurements}

A pin-on-disk tribometer (CSM instruments, Needham, USA) (Figure 2 on the right) was used during the experiments which was modified with the prepared PDMS tribopairs (pin and disc) (Figure 2 on the left). The method was modified based on the method reported by Campbell et al. (2017). The pin and disc were changed after every measument considering the possible effect of surface deformation. The load was set as $0.5 \mathrm{~N}$ as it is done in most of the the literature (Campbell et al., 2017; Van Stee et al., 2017). Tahin and pekmez mixtures were spread on top of the disc in the mould as a thin layer. The disc part was rotating in one direction by the machine while pin was fixed. The speeds used for the each measurement were $5 \mathrm{~mm} / \mathrm{s}, 15 \mathrm{~mm} / \mathrm{s}, 25 \mathrm{~mm} / \mathrm{s}$, $50 \mathrm{~mm} / \mathrm{s}, 100 \mathrm{~mm} / \mathrm{s}, 200 \mathrm{~mm} / \mathrm{s}, 400 \mathrm{~mm} / \mathrm{s}$ and $\sim 525 \mathrm{~mm} / \mathrm{s}$ (the maximum speed that can be adjusted in the equipment). The sample temperature was $25{ }^{\circ} \mathrm{C}$ during the experiments. All measurements were conducted in triplicates.

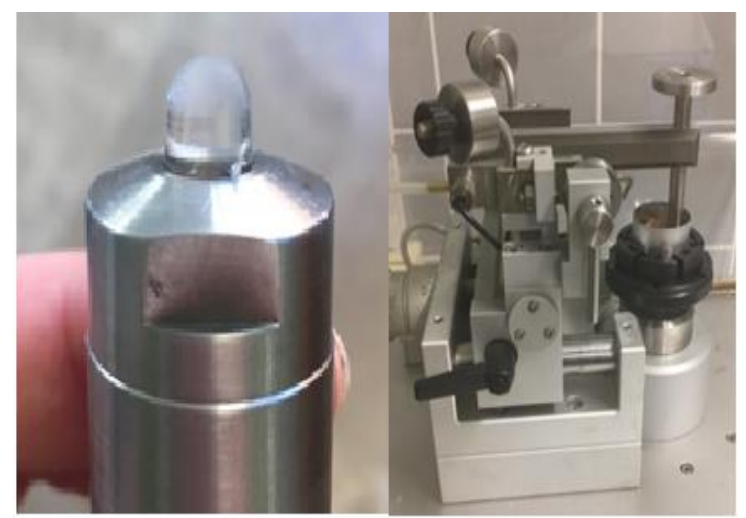

Figure 2. Modified tribometer probe with PDMS pin (on the left) and the CSM tribometer during experiments (on the right).

After each speed measurement, friction coefficients at that specific speed and a standard deviation values were obtained. The Stribeck curves were obtained by plotting the mean values of friction coefficients (-) versus the speeds $(\mathrm{mm} / \mathrm{s})$ used during the experiments.

\section{RESULTS AND DISCUSSION}

The tribology datas for all three samples were presented as the Stribeck curves in Figures 3-6. The average of the friction coefficient means of each three parallel measurements were calculated and plotted against the speed in $\mathrm{mm} / \mathrm{s}$ including standard deviations. The reasons that the obtained deviations might seem a little higher than expected can be lack of calibration in the tribometer and also probe shaking especially in high speeds due to low load of $0.5 \mathrm{~N}$. However, a comparison can still be done using the obtained means in this study. 
As seen from these figures, as the content of tahin increased the maximum friction force decreased. It is clearly seen that when the oil content of the mixture increased depending on the tahin content, the friction decreased. This is especially more profound in the lower speed region for all samples.

As seen from Figure 3-5, the Stribeck curves of the mixtures had different zones corresponding Figure 3, 4, 5 different mechanisms of samples between the two contact surfaces. The zone in which the friction is governed by the internal friction (or viscosity of fluid) and increases linearly with speed is called as hydrodynamic region (Butt et al., 2004; Williams, 2005) It appears that the hydrodynamic regions for each samples started at different points even though they finished at the same speed.

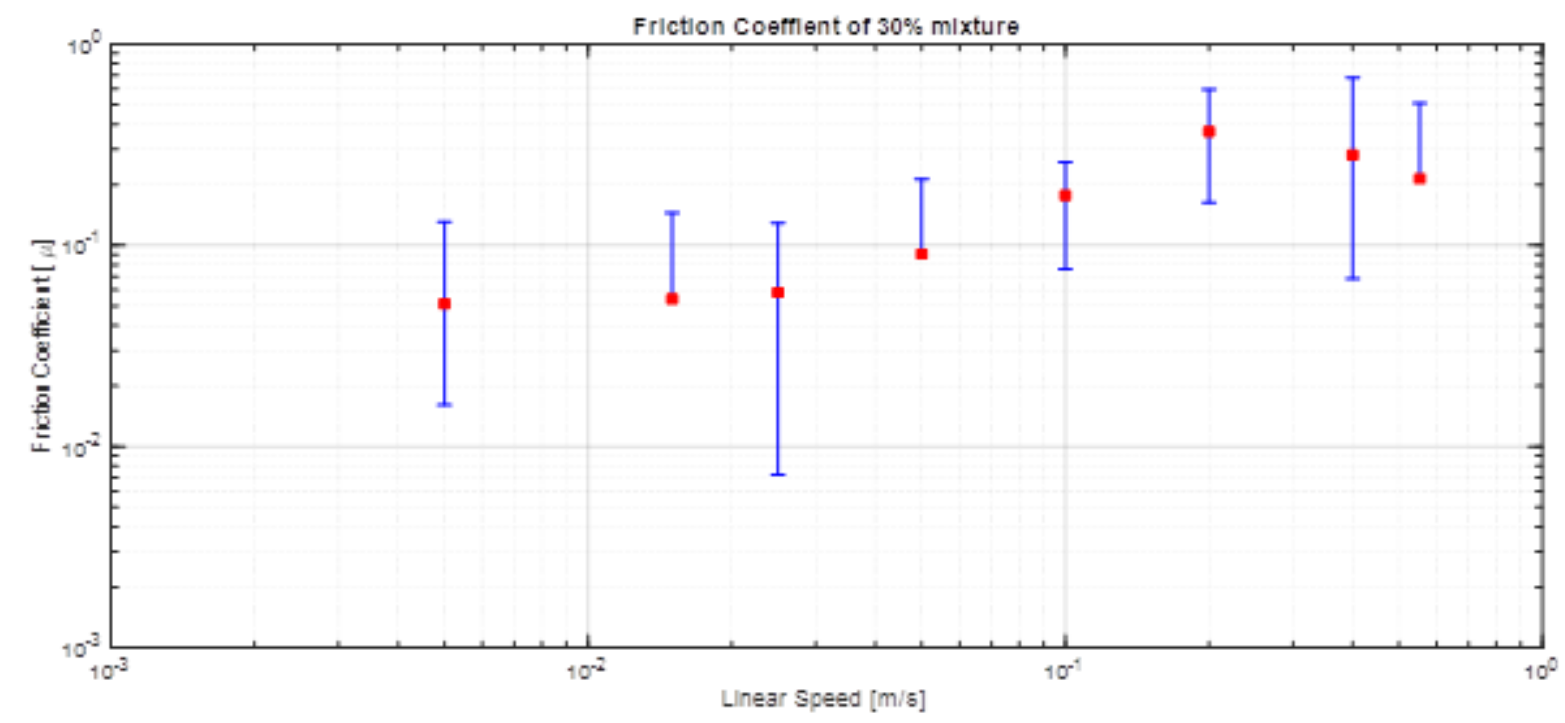

Figure 3. The tribology data for the sample 1 (pekmez:tahin ratio was 30:70)

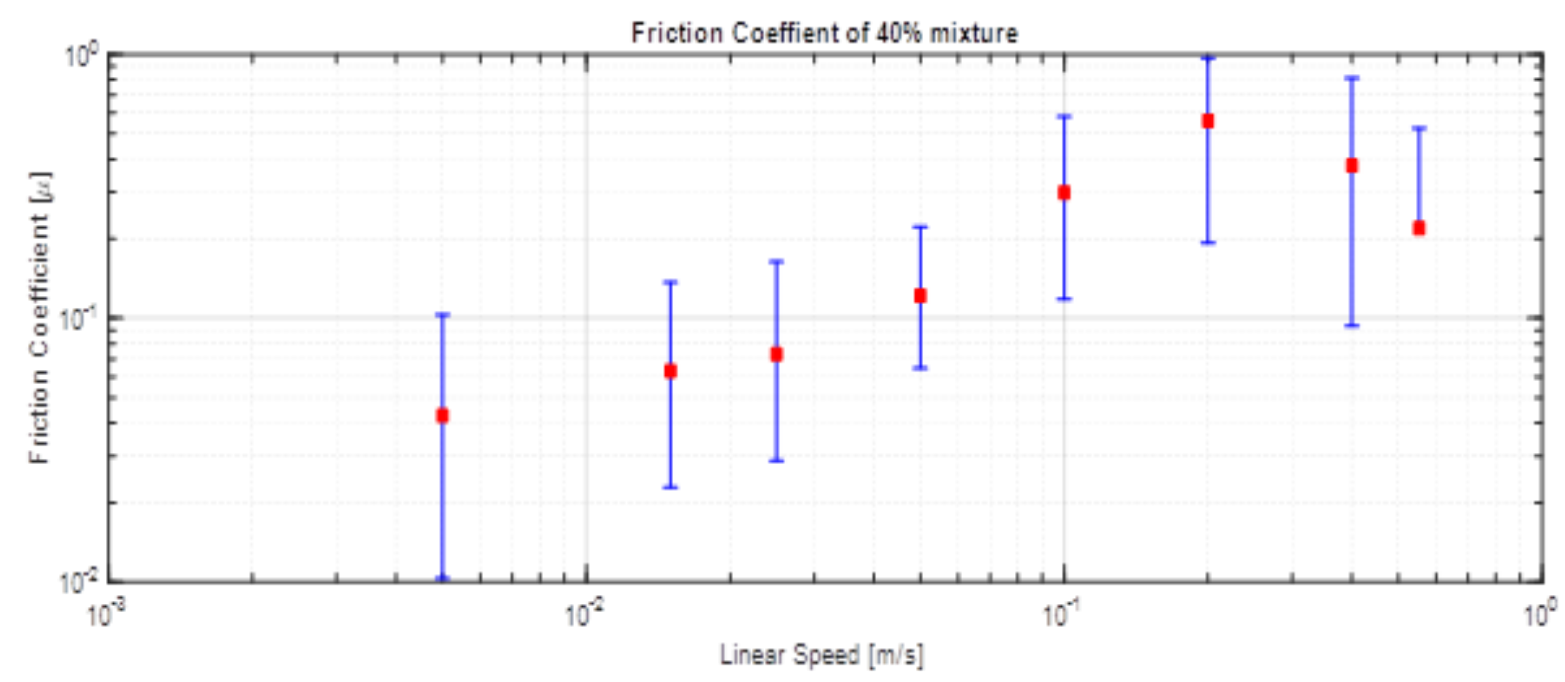

Figure 4. The tribology data for the sample 2 (pekmez:tahin ratio was 40:60) 


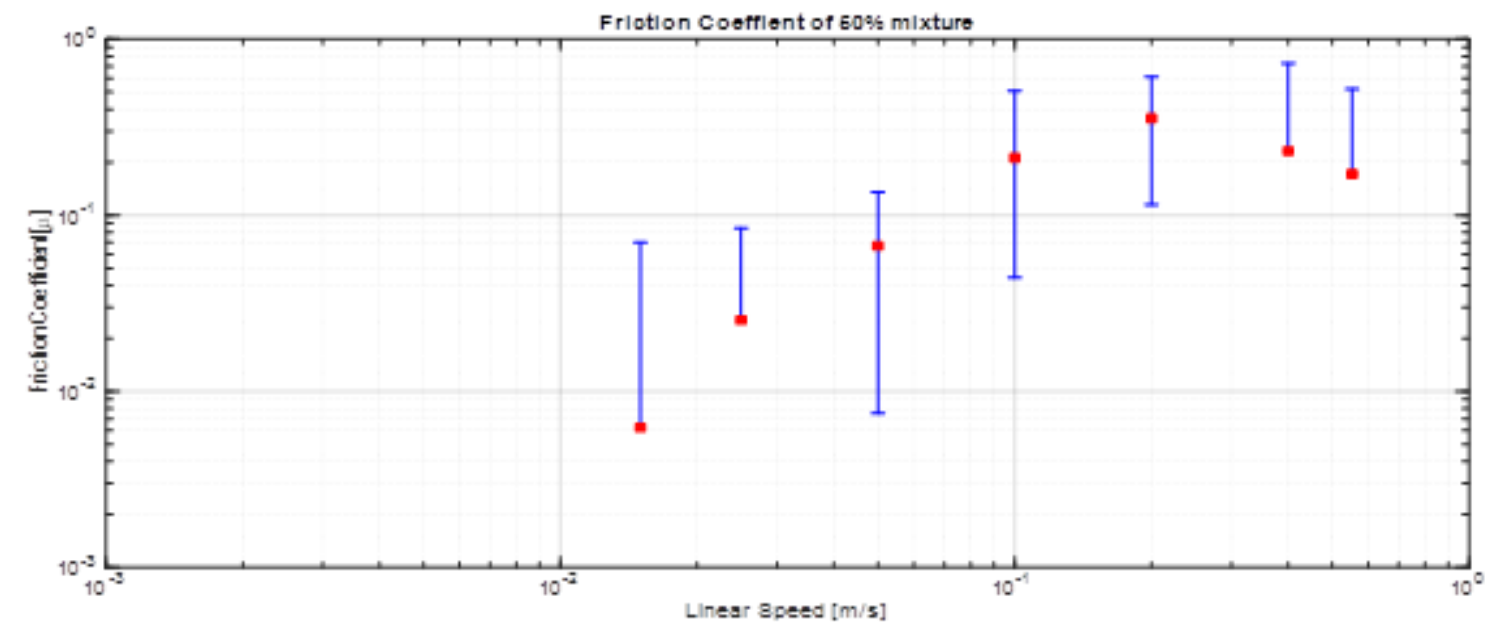

Figure 5. The tribology data for the sample 3 (pekmez:tahin ratio was 50:50)

For instance, the hydrodynamic region for sample 1 (Fig 3) started at $2 \times 10^{-2} \mathrm{~m} / \mathrm{s}$ whereas it was $1.5 \times 10^{-2}$ for sample 2 (Fig 4) and $0.5 \times 10^{-2}$ sample 3 (Fig 5). Probably, the oil content may have an effect on the hydrodynamic region of samples. The friction reached at its maximum at $1 \times 10^{-1} \mathrm{~m} / \mathrm{s}$ for all samples as a thin lubrication film between the contact surfaces developed. After this point, the friction reduced gradually when the sample structures probably broke down at high speeds.

Except for sample 3, the curves showed a relatively constant friction coefficient region at lower speeds. This region is called as boundary region (Nguyen et al., 2017). This boundary region is more clearly seen for the sample 1 (Fig 3) compared to sample 2 (Fig 4). In this region, the two contact surfaces are not affected by the sliding speed or the lubricant viscosity, instead the ability of the sample to adsorb and form a lubrication film between the contact surfaces takes over (Butt et al., 2004).

The lubrication effects of three samples were given in the Figure 6. It can be seen that in different entrainment speeds, all the mixtures shows different friction coefficients. The mixtures with different compositions showed different lubrication behaviours than each other even though some measurement data overlaps at some of the speed parameters (e.g. at $200 \mathrm{~mm} / \mathrm{s}$ for sample 1 and sample 3). Looking at the comparison graph in Figure 6, sample 1 and sample 2 showed higher frictions than sample 3 at low speeds. It is probably due to the higher oil content of the sample 3 . As the speed gets higher (especially after $100 \mathrm{~mm} / \mathrm{s}$ ) the lubrication behaviour started to become similar for all the mixtures but sample 2 showed a higher friction coefficient while sample 1 and sample 3 exhibited very similar coefficient. At the speed of 200 $\mathrm{mm} / \mathrm{s}$ all the mixture samples reaches their maximum friction coefficient.

In rheological measurements, viscosities of the samples with similar compositions would also be similar and generally one can not tell the structural differences easily. The one of the advantage of the tribological measurement over rheological measurement is that tribology may offer a better evaluation for the structural behavior of samples especially during oral processing. From Fig 6, it can be seen that the boundary regions of sample containing 50\% tahin and the other two samples are different (almost one log) at lower speeds. On the other hand the viscosities of the samples 1,2 and 3 at $10 \mathrm{~s}^{-1}$ were 7.31, 7.01 and 5.22 Pa.s, respectively (Akbulut, 2016). 


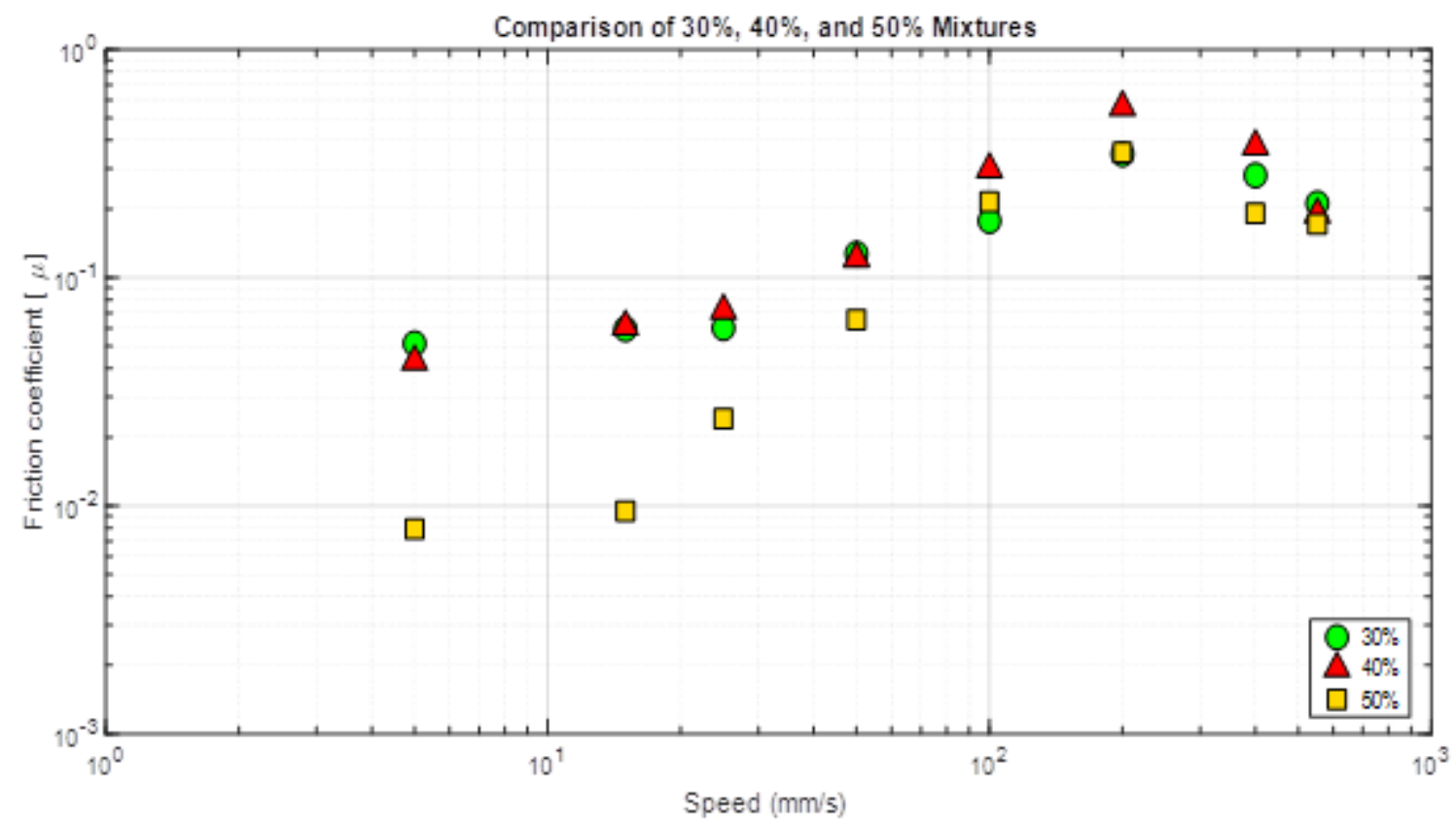

Figure 6. The comparison of tribological data for all samples (circle: sample 1, triange: sample 2, square: sample3)

Arslan et al. (2005) indicated that the average acceptable ratio of pekmez to tahin in the blends as $40-60 \%$. Even though the preference of any given ratio depends on personal choice, it may be explained by the oral processing of the blends from tribological measurements. The friction behavior of samples and the development of a lubrication film in the mouth influence sensory perception (Campbell et al., 2017). Tribological analysis can provide a better understanding of the oral processing for pekmez-tahin mixtures, and this may help to evaluate their sensory perception and eventually overall hedonic liking, which may help to design new food products. These three blends resulted in two distinct tribologic regions (hydrodynamic and boundary regions) in the range of the study. The development of the lubrication film depended on the oil content of the sample. The sample with the least oil content (sample 3) developed the lubrication film between contact surfaces at a lower speed compared to the other samples. This may be attributed that depending on the oral processing in the mouth the sensory perception of the blend may be adjusted with the oil content.

\section{CONCLUSION}

It is important to understand the food texture, structure and mouthfeel characteristics to improve currrent food products and increase their quality as well as consumer acceptability. Textural properties have a big impact on sensory perception during eating which is a dynamic process. Many studies have been conducted to analyse food texture and behaviour using rheological applications but it has been determined that it is not enough to inverstigate whole textual features of a food product after its first bite. Due to certain limitations of rheology, a new field "Tribology" gained popularity where rheology seemed to be insufficient in explaining further steps of oral processing. It has been shown that products even with a really similar rheological properties might show pretty different behavior by using tribological approaches. Plenty of researches and experiments have been done in order to figure out the correlation between sensory properties and in-vitro tribological experiments. Additionally, experimental set up features like surface properties, entrainment speed, saliva, and load or movement effects have 
been discussed and analysed to give a more realistic oral mimicing during food process.

In the experiment conducted during this study, the aim was to show that tribology can provide a better differentiation between the products with similar rheological behaviors. The tribological results obtained from the experiment was satisfactionary since the difference can be seen between the mixtures. It should be noted that although the temperature of $30^{\circ} \mathrm{C}$ is thought to be reasonable for texture-related studies of intraoral surfaces, the experiment was conducted at room temperature and saliva factor was neglected as in most of the studies in the literature. The tribological analyses can be improved by using a better modified tribopair material. For more detailed and clear explanation of these behaviors more experimental analysis should still need to be conducted.

Food tribology still needs some improvement since it has plenty of technological limitations and uncertainties. However, the studies done so far showed a promising potential in association of tribological parameters with sensory and mouthfeel properties.

\section{ACKNOWLEDGEMENTS}

Authors would like to thank Prof. Dr. Ersin Serhatl, Prof. Dr. Birgül Tantekin-Ersolmaz, and Dr. Çiğdem Oral for their help to provide the PDMS kit to adapt the tribometer for our samples. We also would like to thank Prof. Dr. Mustafa Ürgen who provided the tribometer in his lab and research assistant Erkan Kaçar who helped us for conducting experiments with the tribometer.

\section{REFERENCES}

Abu-Jdayil, B., Al-Malah, K., \& Asoud, H. (2002). Rheological characterization of milled sesame. Food Hydrocoll, 16(1), 55-61.

Akbulut, E. 2016. Rheology and sensory characteristics of pekmez-tahin mixtures. Graduation thesis project, ITU Department of Food Engineering, Istanbul, Turkey.
Alparslan, M., \& Hayta, M. (2002). Rheological and sensory properties of pekmez (grape molasses)/tahin (sesame paste) blends. J Food Eng, 54(1), 89-93.

Arslan, E., Yener, M.E., \& Esin, A. (2005). Rheological characterization of tahin/pekmez (sesame paste/concentrated grape juice) blends. $J$ Food Eng. 69, 167-172.

Butt, H.-J., Graf, K., \& Kappl, M. (2004). Friction, lubrication, and wear. In Physics and chemistry of interfaces. Wiley-VCH Verlag $\mathrm{GmbH} \& \mathrm{Co} . \mathrm{KGaA}$.

Campbell, C.L., Foegeding, E.A., \& van de Velde, F. (2017). A comparison of the lubrication behavior of whey protein model foods using tribology in linear and elliptical movement. $J$ Texture Stud, 48, 335-341.

Chen, J., \& Stokes, J. (2012). Rheology and tribology: Two distinctive regimes of food texture sensation. Trends Food Sci Technol, 25(1), 4-12. http://dx.doi.org/10.1016/j.tifs.2011.11.006

Chen, J., Liu, Z., \& Prakash, S. (2014). Lubrication studies of fluid food using a simple experimental set up. Food Hydrocoll, 42,100-105

http://dx.doi.org/10.1016/j.foodhyd.2014.01.00 3

Dresselhuis, D., Dehoog, E., Cohenstuart, M., \& Vanaken, G. (2008). Application of oral tissue in tribological measurements in an emulsion perception context. Food Hydrocol,22(2). http://dx.doi.org/10.1016/j.foodhyd.2006.12.00 8

Foster, K., Grigor, J., Cheong, J., Yoo, M., Bronlund, J., \& Morgenstern, M. (2011). The Role of Oral Processing in Dynamic Sensory Perception. J Food Sci,76(2). http://dx.doi.org/ 10.1111/j.1750-3841.2010.02029.x

Guinard, J., \& Mazzucchelli, R. (1996). The sensory perception of texture and mouthfeel. Trends Food Sci Technol, 7(7), 213-219. http://dx.doi.org/10.1016/0924-2244(96)10025$\mathrm{x}$

Karababa, E., Isikli, N.D. (2005). Pekmez: A traditional concentrated fruit product. Food Rev Int, 21, 357-366. 
Lokumcu, F., \& Ak, M.M. (2000). Rheology of pekmez, tahin, and their mixtures. $2^{\text {nd }}$ International Sypomsium on Food Rheology and Structure, March, 12-16, Zurich, Switzerland.

Malone, M., Appelqvist, I., \& Norton, I. (2003). Oral behaviour of food hydrocolloids and emulsions. Part 1. Lubrication and deposition considerations. Food Hydrocoll, 17(6), 763-773. http://dx.doi.org/10.1016/s0268005x(03)00097-3

Mohammadifar, A., (2017), Rheology in Food Process Operation, DTU Food process design course.

Nguyen, P.T.M., Kravchuk, O., Bhandari, B., Prakash, S. 2017. Effect of different hydrocolloids on texture, rheology, tribology and sensory perception of texture and mouthfeel of low-fat pot-set yoghurt. Food Hydrocoll. 72:90-104.

Prakash, S. (2017). From Rheology to Tribology: Applications of Tribology in Studying Food Oral Processing and Texture Perception. In J. Ahmed, P. Ptaszek \& S. Basu, Adv Food Rheol Appl (pp. 6586). Woodhead.

Prakash, S., Tan, D., \& Chen, J. (2013). Applications of tribology in studying food oral processing and texture perception. Food Res Int, 54(2), 1627-1635. http: //dx.doi.org/10.1016/ j.foodres.2013.10.010
Stieger, M., \& van de Velde, F. (2013). Microstructure, texture and oral processing: New ways to reduce sugar and salt in foods. Curr Opin Colloid Interface Sci, 18(4), 334-348. http://dx.doi.org/10.1016/j.cocis.2013.04.007

Steffe, J.F. (1996). Rheological methods in food process engineering ( $2^{\text {nd }}$ ed.), East Lancing, MI, Freeman Press.

Stokes, J. R. (2012) 'Oral' Tribology, in Food Oral Processing: Fundamentals of Eating and Sensory Perception (eds J. Chen and L. Engelen), WileyBlackwell, Oxford, UK. doi: 10.1002/9781444360943.ch12

Stokes, J., Boehm, M., \& Baier, S. (2013). Oral processing, texture and mouthfeel: From rheology to tribology and beyond. Curr Opin Colloid Interface Sci, 18(4), 349-359. http://dx.doi.org/10.1016/j.cocis.2013.04.010

Van Stee, M., de Hoog, E., \& van de Velde, F. (2017). Oral parameters affecting ex-vivo tribology. Biotribology, 11. http://dx.doi.org/10.1016/j.biotri.2017.05.001

Williams, J. A. (2005). Engineering tribology. New York: Cambridge University Press. 